\title{
STRATEGIC MOTIVATORS AND EXPECTED BENEFITS FROM E-COMMERCE IN TRADITIONAL ORGANISATIONS
}

\author{
Luisa Piris, Guy Fitzgerald and Alan Serrano \\ Brunel University - Department of Information Systems and Computing \\ Uxbridge Middlesex UB8 3PH \\ United Kingdom \\ Tel: +44 (0) 1895 203397-Ext.7036 \\ Fax: +44 (0) 1895251686 \\ luisa.piris@brunel.ac.uk
}

Keywords: e-commerce, strategic information systems, e-business, benefits, strategic motivators. 


\begin{abstract}
This paper aims to identify the strategic motivators and expected benefits related to the implementation of e-commerce infrastructures in traditional "brick and mortar" organisations. Despite the fact that the clearest benefit from e-commerce might be expected to come from contribution to corporate profits, either from an increase of sales or reduction of costs, but this may not be the case. The literature suggests that there are different ways in which the potential benefits can be assessed. These ways are directly related to the evolution of e-commerce. This research has chosen six representative organisations from different sectors to explore their rationales for their e-commerce strategies. One of the main benefits reported is to increase the focus on the customer and improving internal communications. Additionally, obtaining competitive advantage was found to be a powerful motivator, despite the fact that the recent academic literature suggests that this is very difficult to achieve.
\end{abstract}




\section{Introduction}

E-commerce has suffered from the same syndrome as many other theories or new issues that arrive in the business world. Firstly, there was great enthusiasm, organisations had to adapt to the new online world otherwise they would disappear. This was closely followed by the bursting of the dot.com bubble, with some famous failures. In consequence, opinion changed and the literature reflected a radical change in the approach to e-commerce. It was no longer a strategic weapon and its value came to be considered as simply a marketing tool. Finally, the e-commerce approach has been reassessed and it has entered a more mature stage, where some organisations have been able to take advantage of the possibilities of doing business electronically. This general phenomenon is not new. It happened before with theories such as Business Process Reengineering (BPR), TQM, just-in time, or other business panaceas, such as CRM. This paper advocates the idea that e-commerce is currently in a more mature stage and it is no longer a panacea for success. Its value however is recognised and appreciated. At this stage the perception of the benefits and reason to be on-line has changed from the early expectations, mainly based on increasing profit, through sales or cost reduction.

Consequently, the aim of this paper is to explore the strategic motivation and rationale to implement an e-commerce platform in brick and mortar organisations. Those organisations were successfully competing in their own traditional market segments before but after implementing e-commerce strategies all of them reported benefits from e-commerce but most of these were intangible and difficult to measure.

\section{Background}

\section{Definition of e-commerce}

There is no universal agreement on the definition of e-commerce and neither is there a unique theory about the differences between e-commerce and e-business. As a result, each author uses his or her own definitions. All of them however agree with the basic notion that it is about business activities electronically conducted.

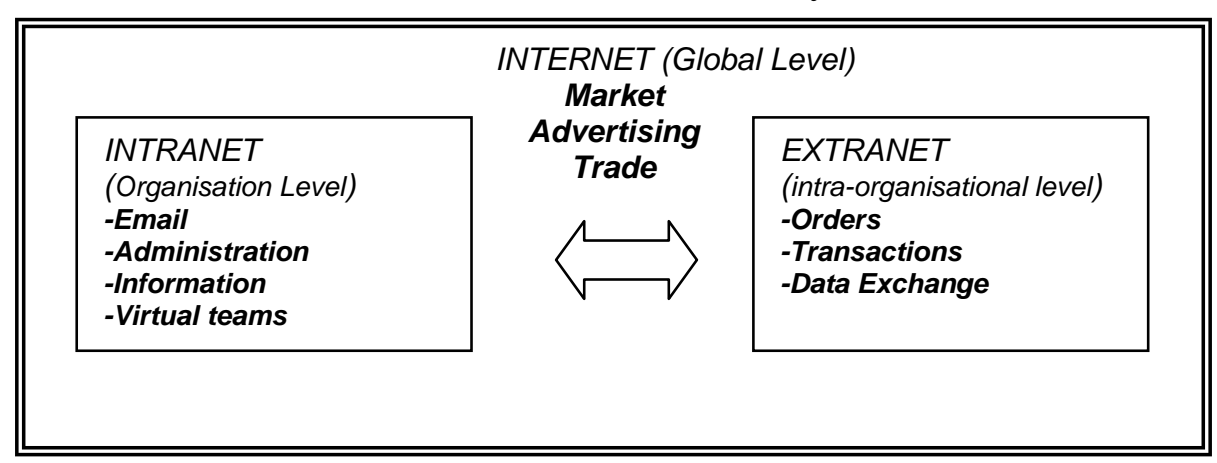

Figure 1 the role of different networks in e-commerce (Adapted from (Lawrence 2000))

In this research, a broad view is taken, closer to e-business. E-commerce is not just buying and selling through the Internet, but also about servicing customers, 
collaboration with business partners, and conducting business internally or within the organisation (Turban 2002). This definition outlines three layers of e-commerce: (i) Intra-organisational, or e-commerce conducted within business, the main exponent is the Intranet and the internal e-mail. (ii) Inter-organisational or business conducted with other business partners; the main exponent is the Extranet. (iii) Finally, there is the most public area or 'the customer to business', which is the most public network open to everyone (Kalakota \& Whinston 1997). The same idea is adopted by Lawrence E. et al. (2000) who defined e-commerce as a group of networks, Intranet or private to the organisation; extranet also private with business partners; and the Internet, which is the public and global network open to everybody (figure 1).

\section{The change in e-commerce perception}

The literature review in this paper can be divided in three different stages. The first one is around 1980 to 1990 when several authors started to argue that competitive advantage could be achieve through the use of Information Systems (Porter \& Millar 1985, Earl 1989, Robson 1997, Galliers \& Baker 1994, Ward \& Griffiths 1996). Information Systems was seen as a truly strategic weapon and various ways of achieving this strategic value were identified.

The second stage begins around the end of 1999 when the first Internet e-commerce systems arose. The literature of that moment still reflected the general enthusiasm. The Internet was perceived as a completely new way with different rules that needed different strategies and theories (Kalakota \& Robinson 1999, Currie 2000). The Internet was perceived as a panacea, able to produce large benefits, address an enormous target market, that would enable global businesses, giving the opportunity to reach clients more effectively than ever before. This assumption was firmly believed at all levels: Governments, banks, consultants, companies, newspapers, executives and the public in general. As a result the new internet based start-up companies were not assessed according to revenues, but on their future immense performance. Consequently, they had a very high but unrealistic market value. The philosophy was to be part of this Internet challenge or to disappear. In the late spring of 2000 the realisation of the over-valuation of the dotcoms occurred and resulted in a stock market crash, with all shares hit but in particular the dotcoms. At this stage, the value of e-commerce initiatives became based on revenues, rather than future potential.

The third stage observed in the literature is very recent and adopts an even more critical view of e-commerce. These authors maintain that the Internet is not so radical but simply a new medium, i.e. just an additional channel of communication (Porter 2001, Carr 2003). Consequently, its importance must be assessed in this light. However, there are some authors who still maintain the strategic importance of ecommerce and its powerful influence on markets and industry structures (Dans 2004)

\section{Benefits and reasons for e-commerce implementation}

Quite different motivators and benefits from e-commerce can be found in the literature. There is a clear difference between the reasons observed in the 90's and more recent studies. This is due to the clear change in the e-commerce perception from the 90's to today, as discussed above. However, in same cases, the previous enthusiastic approach has left a clear lack of trust about e-commerce in some 
organisations, either because they had a previous failure or because they are biased by other failures.

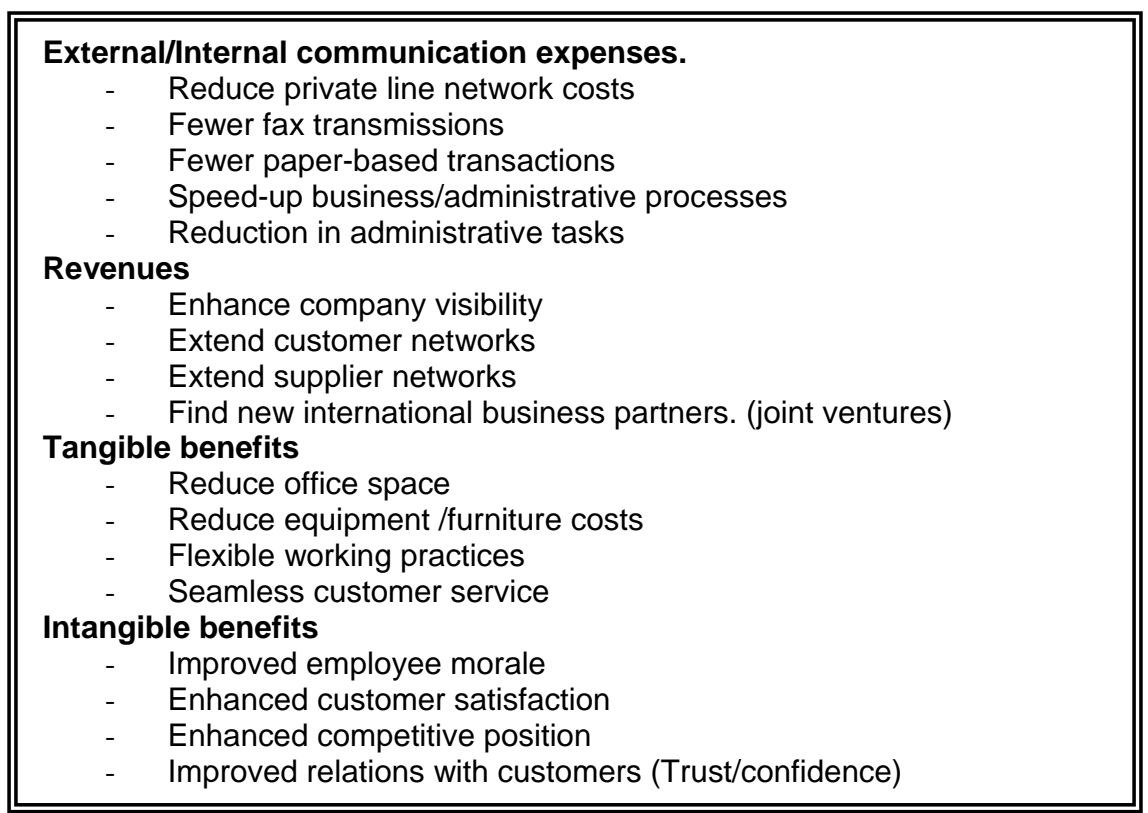

Table 1. Cost/Performance benefits of Internet commerce. Adapted from Currie (2000)

According to Currie (2000), there are several cost/performance benefits of Ecommerce (Table 1): The first benefits are based on reduction of external and internal communication expenses, such as: the speed-up businesses processes and reduced administrative tasks. The second benefits are the revenues generated either from current business or from new initiatives. Theses can also serve to enhance the company's visibility and extend customer and supplier networks. The third group of benefits are tangible benefits; such as reduced costs and more flexible working practices. Finally, there is a group related to intangible benefits, such as enhanced competitive positioning and enhanced customer relationships.

\begin{tabular}{|c|c|}
\hline \multicolumn{2}{|c|}{ Important of Each Benefit (from 1 to 7) } \\
\hline Benefit & Mean \\
\hline -Enhance competitiveness or create strategic advantage & 5.34 \\
\hline -Enable Easier access to information & 5.24 \\
\hline -Provide new products or services to customers & 4.88 \\
\hline -Increase the flexibility of information request & 4.68 \\
\hline -Improve customer relations & 4.66 \\
\hline -Enhance the credibility and prestige of the organisation & 4.57 \\
\hline -Provide better products or services to customer & 4.49 \\
\hline -Increase volume of information output & 4.46 \\
\hline -Align well with stated organisational goals & 4.24 \\
\hline -Enable the organisation to respond more quickly to change & 4.23 \\
\hline -Enable faster retrieval or delivery of information or reports & 4.21 \\
\hline -Help establish useful linkages with other organisations & 4.19 \\
\hline -Save money by reducing communication costs & 4.01 \\
\hline -Increase return on financial assets & 3.93 \\
\hline -Enhance employee productivity or business efficiency & 3.90 \\
\hline
\end{tabular}

Table 2. Benefits of e-commerce. Extracted from Lederer et al. (1996) 
However, those benefits have significant differences in their strategic value. Some of them are quite significant, whereas others are relatively trivial for strategy. A study conducted by Currie (2000) in three organisations (Dell, Cisco, Fedex) highlighted the following benefits: Additional revenues, lower sales/Marketing costs; lower Service/Support Costs, and improve customer relationship. However, the main benefits reported by Leaderer (Lederer, Mirchandani, \& Sims 1996) are more intangible (table 2) and less directly related to increasing profits.

Consequently, the objective of this paper is to compare the perceived benefits of ecommerce in traditional companies, "brick and mortar" and to compare and assess these values. Organisations with strategic perception of e-commerce and those without assess the expected benefits in different ways, although there are some similarities.

\section{Research approach}

A mixed qualitative and quantitative research approach has been undertaken with cases conducted in six different organisations from different activity sectors. The approach was based on the following research framework (see figure 2). Questionnaires were sent to several organisations and case investigations were conducted in a number of others to get a multifaceted understanding. This involved not only interviews of stakeholders but also the analysis of documents and texts and observation of their web-sites and e-commerce initiatives. The findings have been analysed individually and then compared with each other, in order to obtain some patterns and models. Finally the findings from the case studies have been compared with the findings from the literature review. Although, the research approach is identified as mixed, the authors consider it principally as qualitative research due to the focus on understand the scenario rather than the statistical analysis of the data.

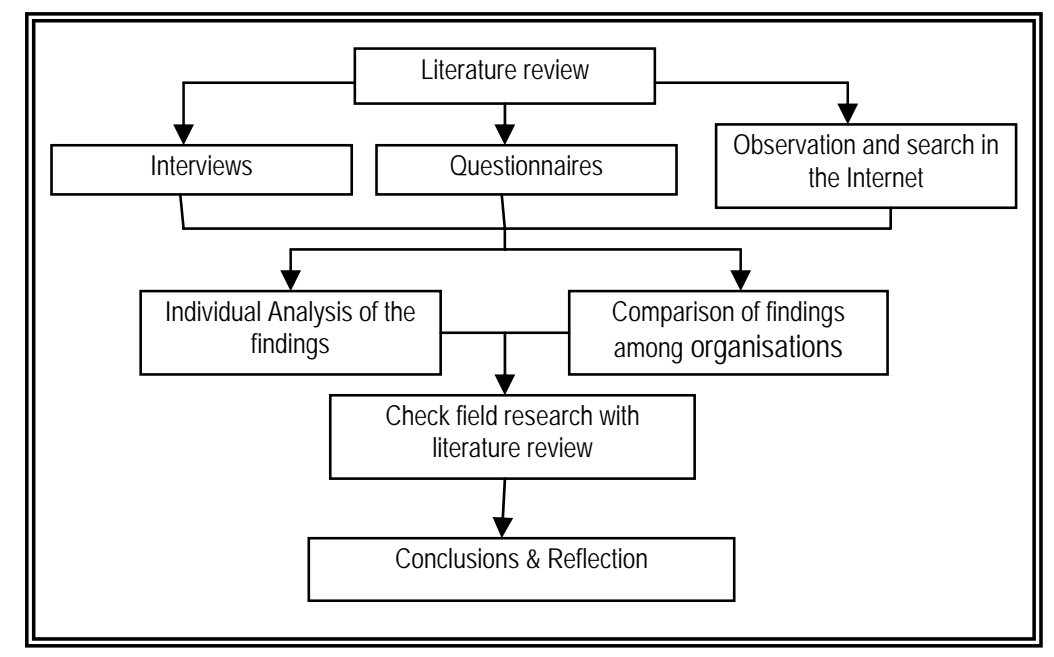

Figure 2. Scheme of research approach employed

The use of a case study approach for this research is because such studies examine the phenomenon in its natural setting and employ multiple methods of data collection to gather information (Benbasat, Goldstein, \& Mead 2002). According to these authors 
the case study is particularly useful when the research is focused on contemporary events and particularly advantageous in studies about the relationship between IT and corporate strategy

\section{Cases Studies}

\section{The participants}

This section contains the results from the field research conducted in the six organisations. Each of those organisations belongs to a different activity sector and can be regarded, to some extent, as representative of that sector due to either their size or importance in the sector. The sectors are; Education, Oil and Gas, Local Government, Alcoholic Beverages, Building materials, and Audit and advisory services. For reasons of confidentiality organisations' names cannot be revealed. As a result, they are labelled as Business School x, Oil x, Borough x, Beverage x, Material $\mathrm{x}$ and Consultancy X. (see Table 3)

\begin{tabular}{|l|l|l|l|l|l|l||}
\hline Company & $\begin{array}{l}\text { BUSINESS } \\
\text { SCHOOL X }\end{array}$ & OILL X & $\begin{array}{l}\text { BOROUGH } \\
\mathbf{X}\end{array}$ & $\begin{array}{l}\text { BEVERAGE } \\
\text { X }\end{array}$ & Material X & $\begin{array}{l}\text { Consultancy } \\
\text { X }\end{array}$ \\
\hline Respondent & $\begin{array}{l}\text { IS/IT area } \\
\text { chair }\end{array}$ & $\begin{array}{l}\text { BI } \\
\text { consultant }\end{array}$ & $\begin{array}{l}\text { Information } \\
\text { System } \\
\text { Manager }\end{array}$ & $\begin{array}{l}\text { Business } \\
\text { Analyst }\end{array}$ & $\begin{array}{l}\text { E-business } \\
\text { Manager }\end{array}$ & $\begin{array}{l}\text { IT\&KM } \\
\text { Director }\end{array}$ \\
\hline Sector & Education & Oil \& Gas & $\begin{array}{l}\text { Local } \\
\text { Government }\end{array}$ & $\begin{array}{l}\text { Alcohol } \\
\text { beverages }\end{array}$ & $\begin{array}{l}\text { Building } \\
\text { materials }\end{array}$ & $\begin{array}{l}\text { Audit \& } \\
\text { Advisory } \\
\text { Services }\end{array}$ \\
\hline $\begin{array}{l}\mathbf{N}^{\circ} \\
\text { Employees }\end{array}$ & $\begin{array}{l}\text { Non } \\
\text { Available }\end{array}$ & +10.000 & $250-999$ & +10.000 & $\begin{array}{l}1.000- \\
10.000\end{array}$ & $1000-10.000$ \\
\hline
\end{tabular}

Table 3. Summary of Organisations, which participated in this research

\section{Business School $\mathbf{x}$}

This organisation is a well-known Spanish Business School, which provides postgraduate courses and Masters degrees. In the international rankings, their Masters are always in the top ten of the world rankings, together with Harvard Business School, LBS, LSE, among others.

Its web site is organised in several areas: Information about the Master courses, executive education, the research centres, the law program, communities of past and current students and professors and lectures, and finally online-courses. It has one intranet, for staff and current students with academic information, corporate e-mail and on-line tools. Another private area or Extranet can be found, with current and past students, professors, staff and lectures. Finally, there is a public or Internet area, open to everyone, which mainly contains information and some interaction tools for prospective students.

It should be noted that this organisation declares in their Mission Statement that they have a firm commitment to new technologies. An important reason is that they have developed an on-line MBA programme, which has been running since 2001 with very good results. The organisation has a strong commitment to those initiatives that are enclosed in the Extranet containing the on-line campus for current students and the e- 
learning initiatives for virtual education. These two areas are perceived as highly strategic.

\section{Oil x}

This organisation is an important multinational company in the oil and gas sector, with its headquarters in the UK and Holland. They have more than 115,000 employees around the world, operating in five continents. The organisation covers all the upstream and downstream stages of the petroleum business. Consequently, they own all the channels from extraction of oil to direct sales to customers, through their own petrol station network.

They define e-commerce as considerably strategic both in the past and nowadays, with a very high investment in the area. They report a budget of between $£ 2.5$ million to 5 million, which is the largest investment reported in this research. Their ecommerce systems are currently integrated with other IS, such as ERP, invoicing and inventory systems. The e-commerce department provides central hosting for all the countries and companies. All the content, on-line tools and processes are managed from their headquarters.

\section{Borough $\mathbf{x}$}

This organisation is a local borough in London. They have between 250 to 999 employees. This is a very particular case of e-commerce, e-government. Egovernment is highly influenced by the UK Government policies. UK government defined as high priority to achieve the target of making all government services available electronically by 2005. For this reason they created the office of e-envoy. It was set-up in 1999 as part of the policies to increase and enhance the presence of electronic government. As a result, they define e-commerce and in this particular case e-government as currently highly strategic. However, it was not strategic in the past. They have their own e-business manager/director who reports directly to the IT director. It is worth noting that the whole e-government activity is outsourced.

\section{Beverage $x$}

This organisation is the world's largest producer of alcoholic drinks and leader in its sector, with more than 25,000 employees around the world and supplying alcoholic drinks in 180 markets around the world. Its headquarters are based in London. UK and Ireland, USA and Spain are the three main markets. It was formed by the merge of two well-know spirits and brewery companies. Its beers and distilled spirits include the most well-know brands.

BEVERAGE $X$ has defined e-commerce strategic now and in the past. The main ideas, which can be perceived from its corporate information and its web sites, are that customer loyalty, strong brand recognition and strong corporate culture are crucial values for the organisation. Their sector is quite mature and the differentiation is significantly difficult. Brand loyalty is one of the main motivators for consumers to choose one beverage instead of another. As a result, the organisation tries to increase these values through their e-commerce strategies. They have several web sites: a corporate web site, various web sites dedicated specifically to each brand and specific web-sites for each country. The organisation undertook a large programme to assess the opportunities held within e-commerce and to acquire a rich understanding of the e-commerce opportunities. 


\section{Material X}

This organisation is a UK multinational company in the building materials sector. They have presence in more than 50 countries with 140 plants and more than 13.000 employees around the world. As a result, they are one of the most important firms in its sector. However, European operations accounts for about half of the company's total sales. Their main products are plasterboard, the material for walls and ceilings and paperboard products, to produce plasterboard and packaging. Other products include fire-resistant board and construction tools, as well as flooring, insulation, and decorative materials.

This organisation currently perceives e-commerce as non-strategic. However, it was more strategic and important two years ago. One of the main arguments given is that the complexity of the channel, where the relationship with the customer is difficult to maintain -the final owner of the house-; disintermediation is not perceived as advantageous. Finally, they do not sell through the Internet. On-line ordering is perceived as difficult to achieve, due to the high level of interaction with the customer. Additionally, the independent policies of each country should be changed in order to have a common best practise in taking orders. Another reason is that the information provided to their customers is not completely open (price, stock, etc). Normally the order taking process implies a negotiation about stock and prices, which is difficult to automate. This process is affected by the fact that complex information is not available at all levels and customer priority levels for backorders are difficult to manage.

\section{Consultancy X}

This organisation is one of the top leaders in the sector of Audit and Advisory Services. They have more than 100.000 professionals around the world in 750 offices in 152 countries. However, although there is a strong relationship among countries, each country is an independent company with their own strategies and policies. Audit service, financial advisory, consulting, legal services, assurance are some of the services they provide.

This organisation defines e-commerce activities as non strategic for them, neither now nor in the past. However, they are quite interest in all the areas related with knowledge management and virtual communities. In fact, the CIO is also the IT manager and Knowledge manager. On the other hand, the responsibility of each country's web-site corresponds to the Marketing Department. This is an important clue, which shows the e-commerce assessment is mainly as a marketing tool. They are not integrated with any other information system, nor there is any intention of future connections. Furthermore, their e-commerce budget is particularly low and the update of pages is also rather low with only two updates per month.

They do not sell any kind of products or services over the Internet, nor have any kind of online tools for customers. Although some of their competitors have defined new products to be offered through the Internet and have some successful e-commerce initiatives. They reported that in general terms they find that e-commerce tools are not applicable to their business. Their main policies are based on people and services provided by its professional staff. However, they have some tools to increase and enhance communication with customers. Nevertheless, they do not have any kind of tool to substitute people by software or e-commerce tools to deliver services to 
customers. It is worth noting that their invoicing systems are based in the hour/person rate.

\section{Findings}

\section{Business School X}

The reasons they mention for developing their e-commerce initiatives were mainly related to increasing the link with customers, enhancing the company image, creating competitive advantage, improving the customer's services and improving flexible working practices. This last reason is mainly because their staff are highly professional and independent. Whereas the reasons related to reducing costs were not taken into account and consequently they are not assessed. In the section related to tangible benefits they have only assessed the increase of sales.

\section{Oil X}

Among the reported reasons for establishing an e-commerce infrastructure were to reduce personnel costs, increase sales, reduce channels and create competitive advantage, and are assessed as 'very important'. The reasons assessed as 'important' were: to reduce operational costs, reduce marketing costs, enhance company image, increase communication with customers, increase the number of new customers, improve customer services, speed-up business/administrative processes, competitive necessity, share knowledge around the organisation, and facilitate communications within the organisation. Two reasons assessed as somewhat important were: to simplify the ordering process and improve flexible working practices. On the other hand, no reason is assessed with less than a ' 3 ' -somewhat important-.

They report that they have estimations of tangible benefits in relation to reduction in costs and in increases in sales.

\section{Borough X}

The reasons identified as 'very important' were: to increase communication with customers, increase the number of new customers and improve customer services. The reasons assessed as 'important' were: simplify ordering process, speed-up administrative processes, share knowledge around the organisation and facilitate communication within the organisation. Reduce operational costs, personnel costs and enhance company image are assessed as 'somewhat important'. Reduce marketing costs, create competitive advantage and competitive necessity were assessed as 'very little importance'. Finally to increase sales and reduce channels were estimated as 'not important'.

They reported that they estimate tangible benefits in the section of reduction of costs. Although, they did not provide any figure.

\section{Beverage X}

The reasons assessed as 'Very important' were to increase communication with customers, improve customer services, speed-up business administrative processes, share knowledge around the organisation, facilitate communication around the 
organisation, and create competitive advantage. This last benefit would be achieved mainly by creating a strong brand recognition and customer loyalty in line with the overall strategy of focusing on some brands and on customer service. However, it is considered rather difficult to achieve sustainable competitive advantage through ecommerce systems. The reasons considered 'important' were: to reduce operational costs, increase sales, a way of disintermediation, increase the number of new customers, simplify the ordering process, and improve flexible working practices. On the other hand, the reasons considered as 'very little important' and 'no interest' were to reduce personnel costs, reduce marketing costs, enhance company image, and competitive necessity.

They reported that they estimate tangible benefits in relation to the reduction of some costs, such as operational costs, by speeding-up processes, by simplifying processes and by increase of sales. The only cost reductions that are not considered are personnel and marketing costs.

\section{Material X}

Focusing on the reasons they reported, it is important to highlight that to reduce human resources costs, increase sales, create competitive advantage and improve flexible working practices were assessed as 'very little importance'. Whereas, on the other hand, to reduce operational costs, reduce marketing costs, enhance company image, increase communication with customers, improve customer services, simplify the ordering process, speed up business/administrative processes, share knowledge and facilitate communication within the organisation are assessed as 'important'.

In the same line as the majority of organisations, there is little estimate of tangible benefits. Neither the reduction of cost, nor the increase of sales are estimated in financial terms, both now and in the future.

\section{Consultancy X}

The only reason they reported as 'very important' was to increase sales and after that with a ' 4 ' or 'important' to facilitate communications within the organisation. They assess as 'very little importance' to enhance company image, competitive necessity and as a way of disintermediation. The reason for this last is that they do not have intermediaries to provide the services. It is important to note that they assess as more important trying to create competitive advantage from e-commerce than as a competitive necessity. It is also important to note that despite its concern about knowledge management they assess as 'somewhat important' the use of e-commerce to share knowledge around the organisation. Other reasons that are assessed with a ' 3 ' or 'somewhat important' are; to reduce operational, personnel and marketing costs, to increase communication with customers, increase the number of new customers, simplify the ordering process, speed-up business/administrative processes, to improve flexible working practices.

There is again no attempt to estimate any tangible benefits, neither in relation to reduction of cost, nor in increase in sales, now and in the future.

\section{Summary of the findings}

The summary of the reasons and their importance rating for each organisation are shown in table 4 . The importance of each motivator was assessed with: 1 (not 
important), 2 (very little important) 3 (somewhat important), 4 (important) to 5 (extremely important).

\begin{tabular}{|l|l|l|l|l|l|l|l|}
\hline & O1 & O2 & O3 & O4 & O5 & O6 & mean \\
\hline REASONS & Import. & Import. & Import. & Import. & Import. & Import. & \\
\hline To reduce operational costs & 1 & 4 & 3 & 4 & 4 & 3 & 3.2 \\
\hline To reduce personnel costs & 1 & 5 & 3 & 2 & 2 & 3 & 2.7 \\
\hline To reduce marketing cost & 1 & 4 & 2 & 3 & 4 & 3 & 2.8 \\
\hline To increase sales & 3 & 5 & 1 & 4 & 2 & 5 & 3.3 \\
\hline To enhance company image & 4 & 4 & 3 & 3 & 4 & 2 & 3.3 \\
\hline $\begin{array}{l}\text { A way of disintermediation (reduce } \\
\text { channels) }\end{array}$ & 1 & 5 & 1 & 4 & 2 & 2 & 2.5 \\
\hline $\begin{array}{l}\text { To increase communication with } \\
\text { customers }\end{array}$ & 3 & 4 & 5 & 5 & 4 & 3 & 4.0 \\
\hline $\begin{array}{l}\text { Increase the number of new } \\
\text { customers }\end{array}$ & 2 & 4 & 5 & 4 & 2 & 3 & 3.3 \\
\hline Improve customer service & 5 & 4 & 5 & 5 & 4 & 2 & 4.2 \\
\hline To simplify the ordering process & 5 & 3 & 4 & 4 & 4 & 3 & 3.8 \\
\hline $\begin{array}{l}\text { To speed-up } \\
\text { business/administrative processes }\end{array}$ & 5 & 4 & 4 & 5 & 4 & 3 & 4.2 \\
\hline To create competitive advantage & 5 & 5 & 2 & 5 & 2 & 3 & 3.7 \\
\hline Competitive necessity & 2 & 4 & 2 & 3 & 3 & 2 & 2.7 \\
\hline $\begin{array}{l}\text { To share knowledge around the } \\
\text { organisation }\end{array}$ & 3 & 4 & 4 & 5 & 4 & 3 & 3.8 \\
\hline $\begin{array}{l}\text { To facilitate communications within } \\
\text { the organisation }\end{array}$ & 3 & 4 & 4 & 5 & 4 & 4 & 4.0 \\
\hline $\begin{array}{l}\text { To improve flexible working } \\
\text { practices }\end{array}$ & 4 & 3 & 5 & 4 & 2 & 3 & 3.5 \\
\hline
\end{tabular}

Table 4. Reasons and Benefits of e-commerce

\begin{tabular}{|c|c|c|c|c|c|c|c|c|c|c|c|c|}
\hline & \multicolumn{2}{|c|}{$\begin{array}{l}\text { BUSINESS } \\
\text { SCHOOL } X\end{array}$} & \multicolumn{2}{|c|}{ OILL X } & \multicolumn{2}{|c|}{\begin{tabular}{|l} 
BOROUGH \\
$\mathrm{X}$ \\
\end{tabular}} & \multicolumn{2}{|c|}{$\begin{array}{l}\text { BEVERAGE } \\
\mathrm{X}\end{array}$} & \multicolumn{2}{|c|}{\begin{tabular}{|l|} 
MATERIALS \\
$\mathrm{X}$ \\
\end{tabular}} & \multicolumn{2}{|c|}{$\begin{array}{l}\text { CONSULTA } \\
\text { NCY X }\end{array}$} \\
\hline & Actual & Future & Actual & Future & Actual & Future & Actual & Future & Actual & Future & Actual & \begin{tabular}{|l} 
Future \\
\end{tabular} \\
\hline $\begin{array}{l}\text { Reduction of } \\
\text { Costs }\end{array}$ & No & & Yes & Yes & Yes & Yes & Yes & Yes & & No & No & \\
\hline Personnel & No & & Yes & Yes & Yes & Yes & No & No & No & No & & \\
\hline Marketing costs & No & & Yes & Yes & Yes & Yes & No & No & No & No & & \\
\hline $\begin{array}{l}\text { Operational } \\
\text { costs }\end{array}$ & No & & Yes & Yes & Yes & Yes & Yes & Yes & No & No & & \\
\hline $\begin{array}{l}\text { By speeding-up } \\
\text { processes }\end{array}$ & No & & Yes & Yes & Yes & Yes & Yes & Yes & No & No & & \\
\hline $\begin{array}{l}\text { By Simplifying } \\
\text { processes }\end{array}$ & No & & Yes & Yes & Yes & Yes & Yes & Yes & No & No & & \\
\hline $\begin{array}{l}\text { Increase of } \\
\text { sales }\end{array}$ & Yes & & Yes & Yes & & & Yes & Yes & No & No & & \\
\hline
\end{tabular}

Table 5. Estimation of tangible benefits.

The summary of the estimation of tangible benefits is shown in table 4 . The objective was to discover if the organisation assessed the economic contribution of e-commerce in the present situation and if they have assessed its possible contribution in the future. The results obtained where unfortunately rather vague. Most of organisations declared that they did not attempt to assess tangible benefits and nor did they provide 
concrete information about the savings obtained. Results are summarized in the table 5 .

\section{Analysis of the results}

\section{Analysis in organisations, which consider e-commerce as strategic}

Four out of the six organisations considered e-commerce as strategic. Although they were from quite different sectors, all of them share some issues in their e-commerce strategies and perceptions.

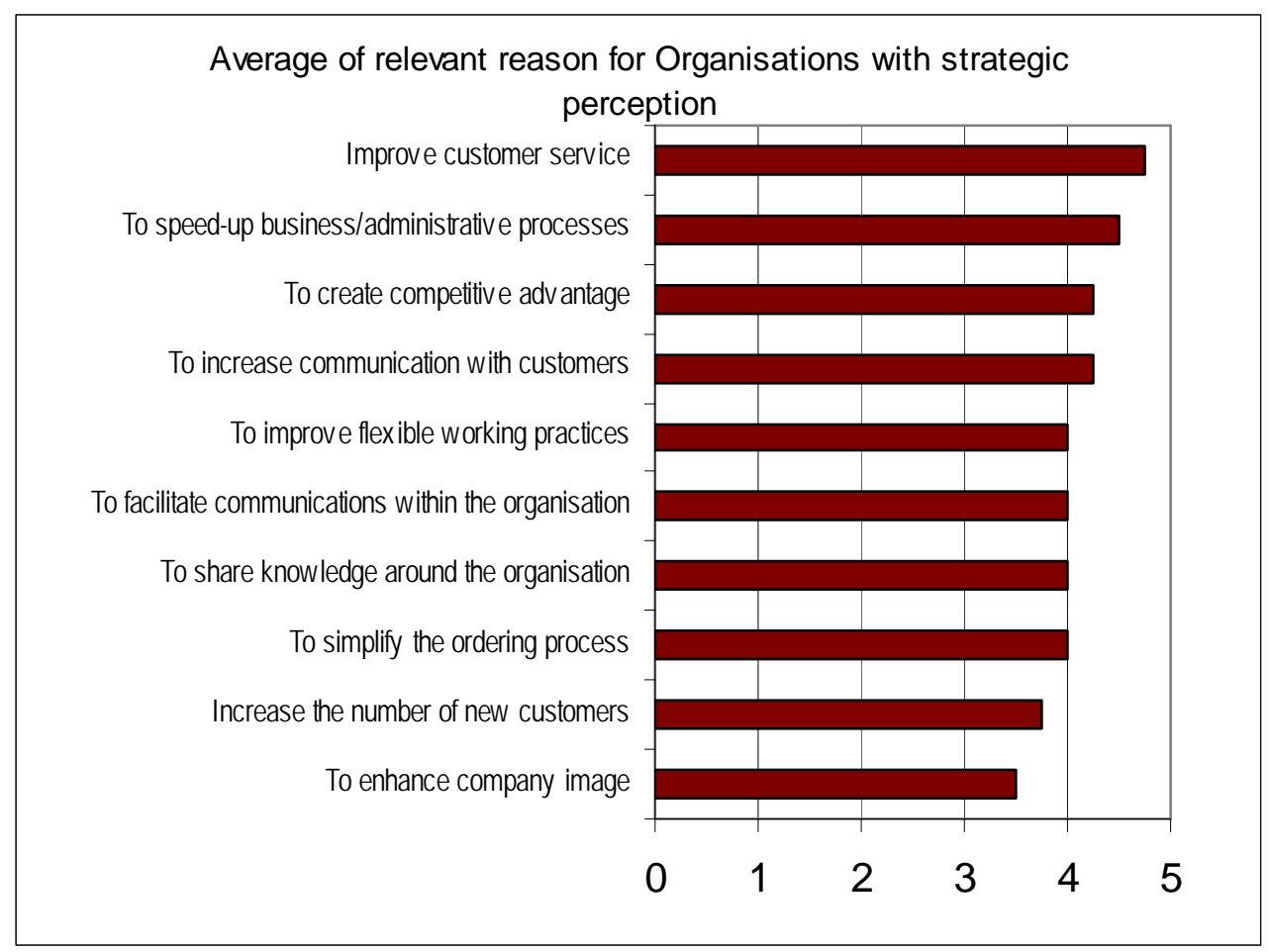

Figure 3. Average of relevant reason/benefits for organisation with strategic ecommerce (more than 3.5 )

Some of the similarities found are: The funds invested in e-commerce are much larger for the organisations with a strategic perception of e-commerce. Clearly their perceptions of the benefits from e-commerce are more optimistic. This is a clear positive return of investment, the more they invest, the more they recover.

The importance of each expected benefit was considered more significant in general, than in organisation without a strategic perception of e-commerce (see Figure 3).

A crucial observation is that the reasons assessed with more that a '4' are: Improve customer services, speed-up business/administrative processes and increase communication with customers. These last two reasons are directly related to improving customer service and add value to their products rather than increment sales, which is not perceived anymore as the major advantage of e-commerce. Another important benefit is to create competitive advantage. Although recent academic literature mainly denies this possibility, organisations still appear to believe 
that this possibility exists. On the other hand, e-commerce is not perceived as a competitive necessity. However, most of the organisations declared that they did benchmarking of their competitors. In conclusion, e-commerce is assessed more as an indirect medium to support and enhance the organisation's strategy.

On the other hand, benefits related to reducing cost, reducing personnel or simplifying their channels are not perceived as imperative. Only reducing operational cost is perceived as 'somewhat important'.

\section{Analysis in organisations, which consider e-commerce as non-strategic}

There are two organisations out of the six, which perceive e-commerce as nonstrategic for their businesses. Perhaps surprisingly there are several similar patterns with those companies that considered e-commerce as strategic. One of the most important is that they do anticipate direct profit from their e-commerce strategies. They do not rate highly either increases in sales nor cost reductions. Hence, their perception about the expected benefits is conditioned by this fact.

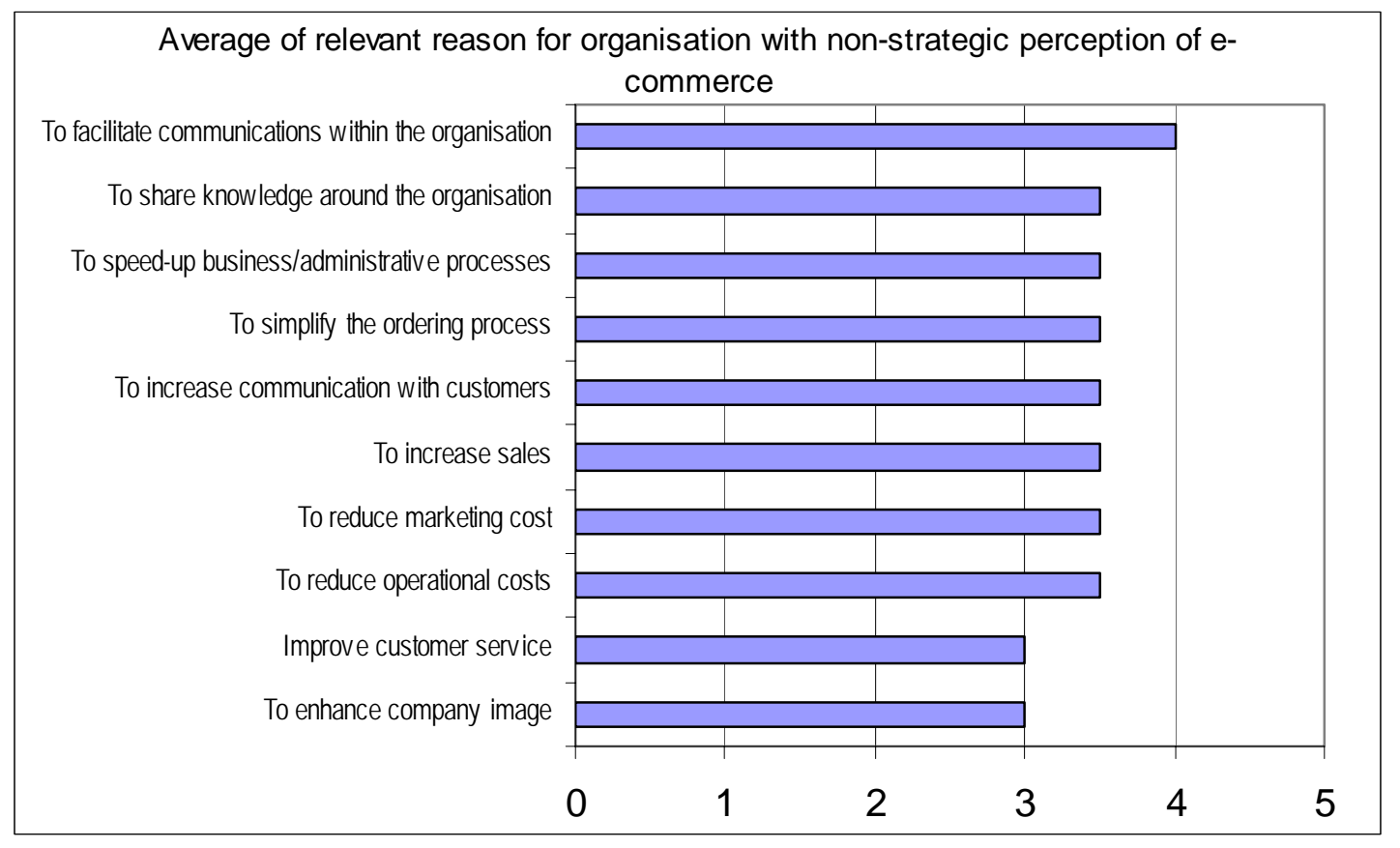

Figure 4 Average of reason/benefits from e-commerce for organisation with nonstrategic e-commerce

The organisations believe that their customers are not particularly attracted by ecommerce systems. Either, because their targeted customer does not match to the typical Internet user or because they perceive the personal relationship with their customers to be very valuable and they feel that it might be lost through e-commerce.

It is worth noting that this research has found evidence that these organisations had a formless strategy about e-commerce (see figure 4). For instance, they did not assess the potential incomes and saving from e-commerce. Furthermore, they focus more internally than externally. The only reason with an average of over or equal 4 (important) is to facilitate communication within the organisation, followed by share 
knowledge around the organisation. All these perceptions show a clear picture of ecommerce as a communication tool.

The least valued benefit was a medium to reduce channels, also of little importance were; to reduce personnel costs, competitive necessity, increase the number of new customers, improve flexible working practise and create competitive advantage. Clearly, this supports their perceptions of e-commerce being non-strategic.

\section{Conclusions}

One of the simplest, but at the same time valuable conclusions, is that those organisations which obtain income and profit through the Internet, are more likely to perceive e-commerce as strategic, whereas those organisations that have no direct revenues through internet, usually have a lower strategic perception of e-commerce. This conclusion is aligned with the research done by Chang, et al. (2003).

Another important finding that arises from the research is that actually the principal use of e-commerce is for increasing and enhancing customer services and as a vehicle to communicate and disseminate information and knowledge (See table 6 and 7).

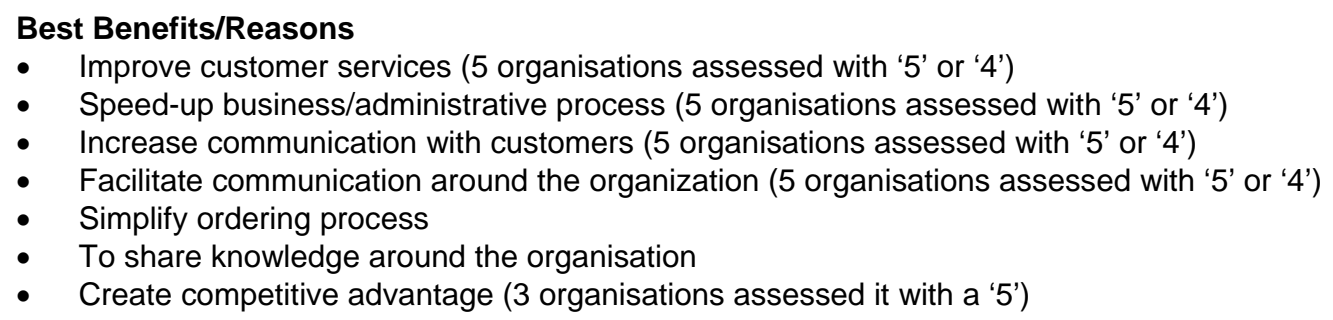

Table 6. Best benefits \& reasons

Despite the fact that recent academic literature declares that obtaining sustainable competitive advantage from e-commerce is difficult to achieve three organisations, out of the four, identified this with a ' 5 ' (see table 6). The majority of organisations with strategic perception of e-commerce still believe that this possibility exists. Despite the fact that most of the organisations declared that they do not benchmark against their competitors they do not perceived e-commerce as a competitive necessity, i.e. e-commerce is now essential rather than providing a competitive edge.

Furthermore, the strategic value of e-commerce applications seems to vary according to the sector. In other words, e-commerce becomes a competitive necessity in those sectors where competition is very aggressive and competitors are making intensive use of it. Whereas, in those other sectors where the use of e-commerce is less common, it is not perceived as an essential strategy and their e-commerce infrastructure are less developed and complex. However, in these sectors where there is very little competition, the possibilities of gaining advantage from e-commerce could be significant. 


\begin{tabular}{|c|c|}
\hline & Most Valuable Benefits \\
\hline BUSINESS SCHOOL X & $\begin{array}{l}\text {-Create competitive advantage } \\
\text {-Improve customer services. } \\
\text {-Speed-up business administrative processes. } \\
\text {-Simplify ordering process. }\end{array}$ \\
\hline OILL $X$ & $\begin{array}{l}\text {-Create competitive advantage } \\
\text {-Reduce personnel costs } \\
\text {-Increase sales } \\
\text {-Reduce channels }\end{array}$ \\
\hline BOROUGH X & $\begin{array}{l}\text {-Increase communication with customers } \\
\text {-Increase the number of new customer } \\
\text {-Improve customer services } \\
\text {-Improve flexible working practices }\end{array}$ \\
\hline BEVERAGE X & $\begin{array}{l}\text {-Create competitive advantage } \\
\text {-Improve customer services } \\
\text {-Speed-up business processes } \\
\text {-to share knowledge around the organisation } \\
\text {-to facilitate communication within the organisation }\end{array}$ \\
\hline MATERIALS X & $\begin{array}{l}\text { *(Non of them were assessed wit ' } 5 \text { ') } \\
\text {-Reduce operational costs } \\
\text {-Reduce marketing costs } \\
\text {-Enhance company image } \\
\text {-Increase communication with customers } \\
\text {-Improve customer services } \\
\text {-Simplify ordering process } \\
\text {-Speed-up administrative processes } \\
\text {-Share knowledge around the organisation } \\
\text {-Facilitate communication within the organisation. }\end{array}$ \\
\hline CONSULTANCY $\mathrm{X}$ & $\begin{array}{l}\text {-Increase sales } \\
\text {-To facilitate communications within the organisations. }\end{array}$ \\
\hline
\end{tabular}

Table 7. Comparisons II. Most valuable reason.

It is important to highlight the value of channels. Those organisations with very complex channels or without direct relationship with the final customer, normally reject the idea of selling through e-commerce. They assessed their channels as especially important and they refused to disintermediate (eliminate their channels). Indeed, their channels were adding value to the product. The more value they add to the product the more essential they are perceived by the organisations.

Finally, further research in the topic would be need with a larger sample of organisations from different activity sector. It might explore the factors in different ecommerce models.

\section{Acknowledgments}

We would like to thank all the organisations, which participated in this research. They found time to help us, despite their busy agendas. Without their contributions this research would have been unfeasible. 


\section{REFERENCES}

Benbasat, I., Goldstein, K.D. \& Mead, M. 2002, "The Case Research Strategy in Studies of Information Systems" in Qualitative research in information systems : a reader, eds. M.D. Myers \& D. Avison, SAGE, London.

Carr, M. 2003, "IT doesn't matter", Harvare Business Review, vol. may.

Chang, K., Jackson, J. \& Grover, V. 2003, "E-commerce and corporate strategy: An executive perspective", Information \& Management, vol. 40, no. 7, pp. 663.

Currie, W. 2000, The global information society, Wiley, Chichester.

Dans, E. 2004, "IT does matter", European Business Forum (EBF), , no. Issue 16.

Earl, M.J. 1989, Management strategies for information technology, Prentice Hall, New York ; London.

Galliers, R. \& Baker, B.S.H. 1994, Strategic information management : challenges and strategies in managing information systems, Butterworth Heinemann, Oxford.

Kalakota, R. \& Robinson, M. 1999, E-Business : roadmap for success, AddisonWesley, Reading, Mass. ; Harlow.

Kalakota, R. \& Whinston, A.B. 1997, Electronic commerce : a manager's guide, Addison-Wesley, Reading, Mass. ; Harlow.

Lawrence, E. 2000, Internet commerce : digital models for business, 2nd edn, Wiley, Brisbane ; Chichester.

Lederer, A.L., Mirchandani, D.A. \& Sims, K. 1996, "Electronic commerce: a strategic application?", Proceedings of the 1996 ACM SIGCPR/SIGMIS conference on Computer personnel researchACM Press, , pp. 277.

Porter, M.E. 2001, Strategy and the internet.

Porter, M.E., Millar, V.E. 1985, "How information gives you competitive advantage", Harvard Business Review, vol. 63, no. 4, pp. 149-160.

Robson, W. 1997, Strategic management and information systems : an integrated approach, 2nd edn, Pitman Publishing, London.

Turban, E. 2002, Electronic commerce 2002, Prentice Hall.

Ward, J. \& Griffiths, P.M. 1996, Strategic planning for information systems, 2nd edn, Wiley, Chichester ; New York. 